\title{
Groundwater Vulnerability and Hazard Mapping in an Arid Region: Case Study, Amman-Zarqa Basin (AZB)-Jordan
}

\author{
Mustafa Al Kuisi' ${ }^{1}$, Kholoud Mashal2, Mohammed Al-Qinna², \\ Abdallah Abu Hamad', Armin Margana ${ }^{3}$ \\ ${ }^{1}$ Department of Applied Geology and Environment, The University of Jordan, Amman, Jordan \\ ${ }^{2}$ Department of Land Management and Environment, The Faculty of Natural Resources and Environment, \\ The Hashemite University, Zarqa, Jordan \\ ${ }^{3}$ Federal Institute for Geosciences and Natural Resources (BGR), Hannover, Germany \\ Email: mkuisi@gmail.com
}

Received 10 January 2014; revised 8 February 2014; accepted 2 March 2014

Copyright (C) 2014 by authors and Scientific Research Publishing Inc.

This work is licensed under the Creative Commons Attribution International License (CC BY). http://creativecommons.org/licenses/by/4.0/

(c) (i) Open Access

\section{Abstract}

The importance of groundwater portability and the possible sources of anthropogenic contamination have led to the development of intrinsic groundwater vulnerability mapping. In this study, groundwater vulnerability map for Amman Zarqa Basin (AZB) has been generated based on information derived and calculated from processed remote sensing information and laboratory analysis. The database was prepared from soil hydro geological and hydrological data, Digital Elevation Model (DEM), and geological maps. For assessment of groundwater vulnerability, the method proposed by the state geological surveys of Germany (GLA-method) has been adapted and applied. The vulnerability map shows about $77 \%$ which is about $2919 \mathrm{Km}^{2}$ of the AZB is classified as very low to low which could be corresponding to the pollution sources due to the absence of potential hazards and also due to low vulnerabilities. These areas could consequently be interesting for future development as they set preferable in view of ground water protection. In addition, about $14 \%\left(530 \mathrm{~km}^{2}\right)$ is classified within the moderate vulnerability zone. About $5 \%$ (around 19 $\mathbf{k m}^{2}$ ) of the study area lies under the area of high vulnerability zone. Only $4 \%$ can be classified as very high risk areas. Groundwater quality results revealed that water leach ate from point source is the main cause for groundwater contaminations in highly vulnerable karstic limestone aquifer (Amman Wadi Es Sir Aquifer-B2/A7). On the other hand, the Kurnub Sandstone aquifer (K) is generally well protected in the central and eastern part of the AZB due to its thick cover of partly marly sequences. However, the Kurnub aquifer might have a potential risk from the recharged infiltrating surface water from the Zarqa River, which is highly polluted due to industrial activities located along the river. 


\section{Keywords}

\section{Groundwater; Vulnerability; Hazard; Selenium; Amman; Zarqa; Jordan}

\section{Introduction}

Groundwater is a vital natural resource for the economic development and secure provision of drinking water, especially in arid and semi-arid areas, that experience shortage of water resources. Groundwater can be degraded in quality by contamination, and this can pose serious concerns, as once a groundwater resource gets polluted; remediation becomes incredibly difficult requiring a long time and large budget [1]. The pressure on groundwater, in terms of both quantity and quality, has increased to an extent whereby not only drinking water sources but also sensitive ecosystems are threatened by contamination through human exploitation. Increasing demand for water, a growing use of pesticides and fertilizers, atmospheric deposition and numerous point sources of contamination constitute a threat to the quality of groundwater [1].

Groundwater resource pollution hazard refers to the probability that groundwater in the aquifer will become contaminated with concentrations above the corresponding guideline value for drinking water quality [2]. Hazards are the activities and developments, which pose a threat to groundwater [2]. The hazard is normally assumed to originate at the ground surface (potential release of a contaminant), and the risk of contamination to groundwater includes the potential consequences of a contamination event [3]. This has led researchers to introduce techniques to evaluate the potential risks to the groundwater resources in the form of "groundwater vulnerability" that was first used in the 1960s [4]. Groundwater vulnerability is a concept based on the assumption that the physical environment provides some natural protection to groundwater against human impacts, especially with regard to contaminants entering the subsurface environment. It is defined as the tendency or likelihood of contaminants reaching the groundwater system after introduction at the surface and is based on the fundamental concept that some land areas are more vulnerable to groundwater contamination than others [5]. Groundwater vulnerability deals only with the hydrogeological setting and the natural hydrogeological factors affecting the range of pollutant types in different ways depending on their interactions and chemical properties [6]. Groundwater vulnerability is a relative, dimensionless property that is not directly measurable and does not include pollutant propagation and attenuation. There are two general types of vulnerability assessments. The first addresses specific vulnerability, which is referenced to a specific contaminant, contaminant class, or human activity. The second addresses intrinsic vulnerability, which does not consider the attributes and behavior of specific contaminants and encompasses all pollutant sources [7].

Several methods of intrinsic vulnerability mapping of groundwater were reported. However, a small number of these methods are specialized in handling karstic aquifers such as, COST 65, GLA German method [3] [8], [9] [10]. The GLA method can be applied to all types of aquifers by providing special methodological tools for karst and is based on an origin-pathway-target model [11] [12]. The term 'origin' is used to depict the location of a potential contaminant release while the "pathway" involves the passage of potential contaminants from the point of release to the "target". One method for mapping vulnerability within the framework of COST 620 is the PI method: Protective cover and Infiltration capacity method [11] [12]. P and I factors are used in the vulnerability assessment especially in karstic aquifers as they are described in [10] and in the final report of the European COST Action 620 [3].

An important output of groundwater vulnerability assessment is the groundwater vulnerability maps. These are important tools for groundwater management that provide basic information for facilitating proper planning and protection of groundwater resources, as well as indicating which target areas should be given priorities for groundwater monitoring and protection.

In Jordan, groundwater constitutes the prime source of water supply, as surface water is very limited. Following many years of drought, water resources in Jordan have been overstressed and suffering from quantity and quality degradation for more than two decades, due to increased urban development. The Gulf wars and regional political conditions forced huge fluxes of immigrants to move into the country either temporarily or permanently, exerting extra stresses on the infra-structure and the already, quantitatively and qualitatively, exhausted water resources [13]. Recent studies indicated a decline in groundwater level of about 20 to $30 \mathrm{~m}$, accompanied with 
deterioration in quality during the last 3 decades [13] [14]. The groundwater depletion has impacted several sectors, namely agricultural and human health. Such impacts made the protection of the source and its management a major priority in the country. The Ministry of Water and Irrigation (MWI) in cooperation with the German Institute BGR proposed groundwater protection guidelines issued in 2006. In addition to issuing a new by-law that addresses protection of groundwater resources through appropriate land use restrictions. Recently, groundwater vulnerability mapping and delineation of groundwater protection zones were implemented in Jordan Valley and Ruseifa areas [13].

The present study aims at examining the practical application of vulnerability mapping method that presents all the climatic, geological and hydro geological characteristics of the Amman Zarqa Basin (AZB). The GLA German method [8] with P and I factors is followed in this study as the method is suitable for all aquifers including karst aquifer. This is due to the fact that AZB contains sandstone aquifer and karst limestone aquifer. Vulnerability maps for the different aquifer types will be produced to form useful tools to the decision makers for providing better legislations, laws, policies and regulations to protect groundwater reserves in the study area.

\section{Physiography, Geology and Hydrogeology of the Study Area}

The study area is located in the northern central part of Jordan which includes the largest two cities, the capital City of Amman with 2.8 million inhabitants and the City of Zarqa with 0.8 million inhabitants [15], in addition to several other towns as shown in Figure 1.

The basin's surface water network which includes the main tributaries, the Zarqa River and Wadi Ad Dulail, drains from the highlands northeast and west of Amman into the Jordan Valley, reaching the Jordan River about 65-km south of Lake Tiberius. The basin is topographically and hydro geologically dominated by a feature known as the Amman-Zarqa flexure which runs in a direction of about 60. To the southeast of it the bases of the geological units are up to $300 \mathrm{~m}$ higher than in the Amman-Zarqa area.

Geologically, the area is dominated by outcrops that are ranging from Triassic to Recent in agewhere the Cretaceous sediments are most dominant. Quennel [16] has classified the Upper Cretaceous formations into Ajlun and Belqa Groups, consisting of various types of limestones, phosphorite marl, chert, and porcellanite [17]. They are underlain by Lower Cretaceous Kurnub Group that best outcrops at Baqa'a along the axis of Suweilehstructure and along Zarqa River valley. The northeastern part of the basin is largely covered with basalt (Figure 2). Most of the formations in the study area are affected by orogenetic movements especially by the Alpine orogenesis of the Maastrichtian causing folding, faulting, synclines and anticlines [18] [19]. The study area is dominated by faults of variable throws and strikes and by several anticlines and synclines. The vertical displacement along faults can be clearly indicated by the movements of the prominent massive limestone cliffs. One of the major structures is the Amman-Hallabat Flexure which is a compressional belt and the associated faults trending and northeast (NE)-southeast (SE) parallel to the upper Zarqa River, approximately $5 \mathrm{~km}$ south of Amman. This fault system has a maximum displacement of about $300 \mathrm{~m}$ and is thought to place the Amman and Wadi Es Sir Formations against the impermeable Muwaqer Formation, by forming a barrier to groundwater flow into the Azraq Basin and diverting the generally north-easterly flow north westwards Wadi Zarqa [20]. Three aquifer systems recognized in AZB are: Basalt, Amman-Wadi Sir Limestone aquifer (B2/A7) and the Kurnub sandstone (K) aquifer. The northeastern part of the AZB is covered with basalt, which forms the major aquifer in the Badia area (NE desert). It overlies the B2/A7 aquifer but has a much higher permeability. Unfortunately, its salinity and nitrate content have increased over the past two decades due to intense irrigation in the Badia.

Groundwater contour maps for the B2/A7 and Kurnub aquifers are shown in Figures 3 and 4, respectively. Figure 3 reveals that the limit of saturation extends towards NE-SW direction and the groundwater flow is controlled by the main geological structure, Amman-Hallabat Flexure, which acts as a barrier for groundwater flow. However, the Flexure raises the hydraulic head in the saturated zone to more than $900 \mathrm{~m}$ above sea level.

The Kurnub aquifer is unconfined in much of the area following an imaginary line between the cities of Amman, Jarash and Mafraq (Figure 4). The depth to Kurnub aquifer in most areas of AZB is less than $500 \mathrm{~m}$. In the area between Hallabat and Zarqa, the water level of the Kurnub aquifer is less than $200 \mathrm{~m}$ below ground surface and the Kurnub aquifer is fed by downward leakage from the (basalt)-B2/A7 aquifer. This area would therefore, offer a good opportunity to protect the Kurnub aquifer. In addition, the hydraulic head difference between B2/A7 and Kurnub aquifer (Figure 5) is almost zero in the border region east of Mafraq and increases towards SW, reaching 250 to $300 \mathrm{~m}$ in the Amman area and in the Yarmouk Basin, in the northern part of Jordan the Kurnub is under high artesian pressure [13]. 


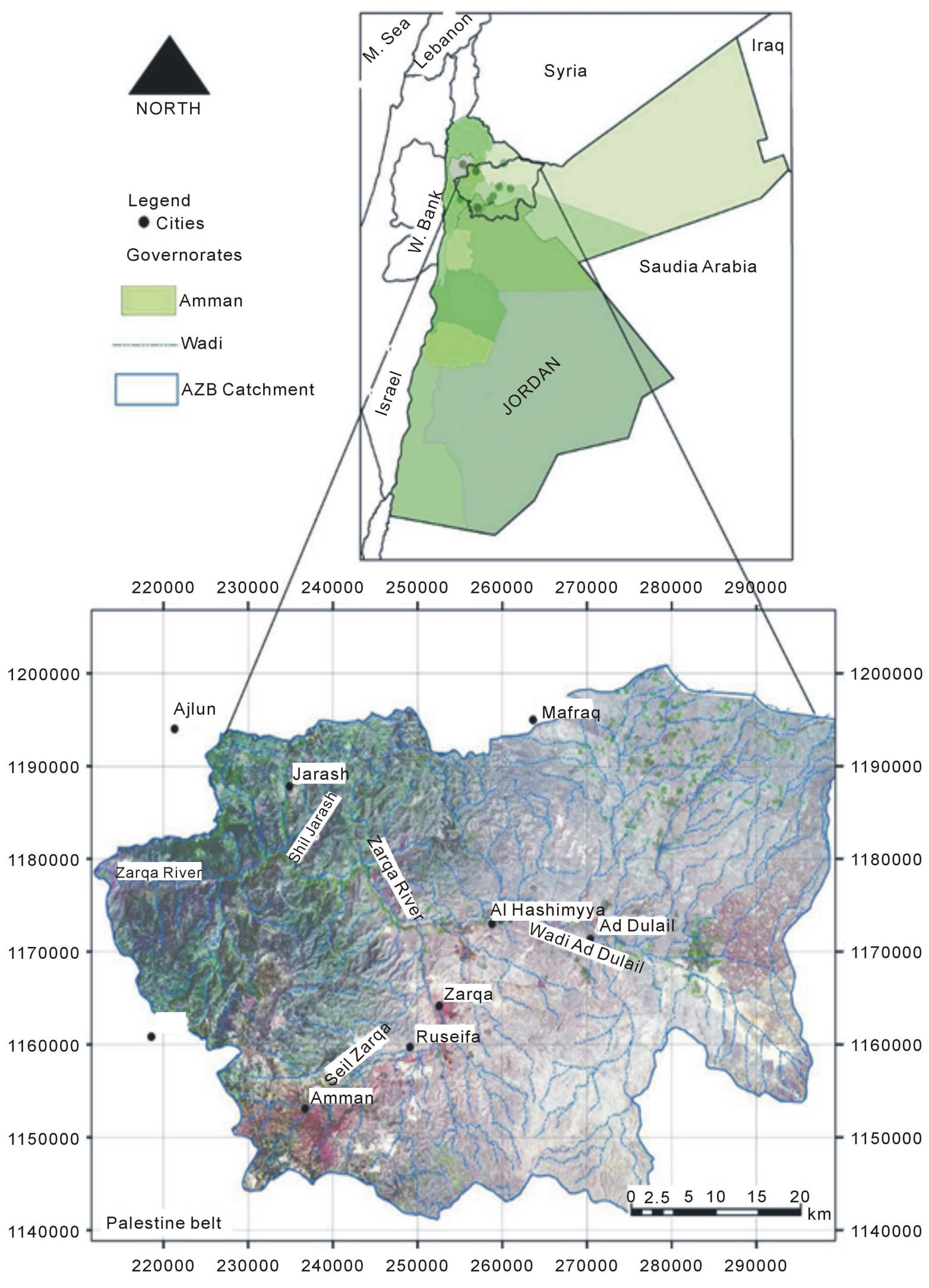

Figure 1. Location map for Amman Zarqa Basin (AZB). 


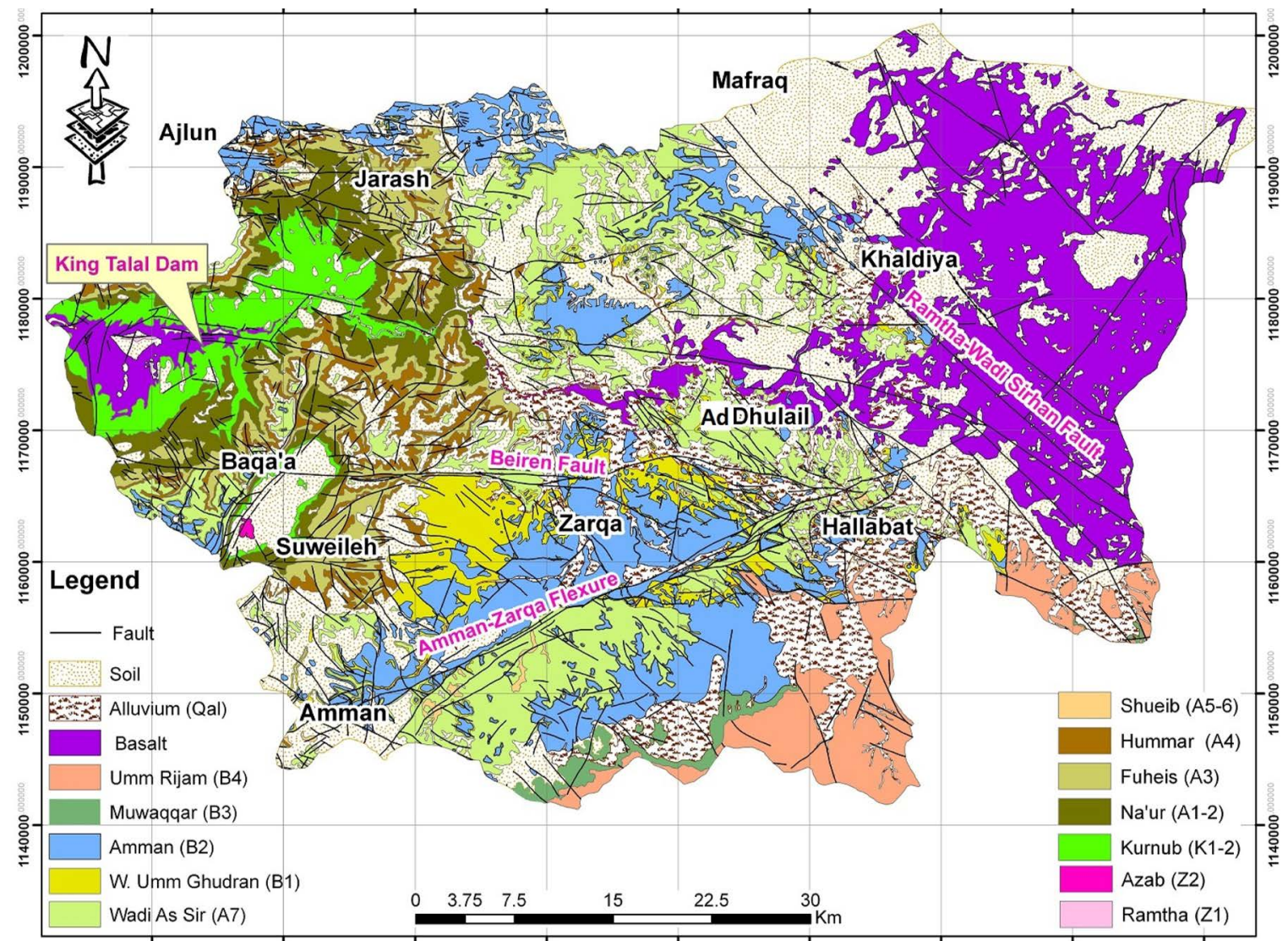

Figure 2. Geological and structural map of AZB [18].

\section{Groundwater Conditions of the Study Area: Amman Zarqa Basin}

The Amman Zarqa Basin (AZB) is the most important basin in Jordan covering an area of about $3566 \mathrm{~km}^{2}$ (Figure 1). Since early 1990s, tremendous industrial development took place in the AZB. Most of the industrial enterprises were constructed without provisions for adequate treatment of wastewater or safe disposal of waste. Although an environmental law was issued on 2006 after the Ministry of Environment (MoEnv) was founded in 2003, environmental regulations are not yet sufficiently implemented. Currently, wastewater and solid wastes from industrial enterprises are still not adequately managed in the AZB and thus exerting environmental risks, and potential hazards to groundwater resources. The basin is also one of the transitional areas between the highlands in the west and the desert in the east. The variation in altitudes is not only reflected in the climatological changes but also in different land use patterns. The major land use types existing at AZB include $65 \%$ of bare rock with thin soils and urbanization and $35 \%$ of natural vegetation, forest, irrigated agriculture and rainfed agriculture. The mean annual rainfall at the basin is about $300 \mathrm{~mm}$ and the mean annual stream flow is about 63 million cubic meters (MCM). The groundwater safe yield of the basin is about $65-70 \mathrm{MCM}$, while the abstraction rate exceeds 140 MCM [21] with Amman area consuming about 40 MCM from the groundwater for municipal uses. Similarly, industries in the basin consume about 8 MCM annually while estimated extractions for annual irrigation are about 110 MCM. The annual effluent of the wastewater treatment plants totals about 60 MCM which is used in irrigation, mainly in the southern part of the Jordan Valley [21].

\section{Methodology: Intrinsic Vulnerability Mapping}

When assessing the vulnerability of groundwater to contamination, the protective effect of rocks and superficial deposits covering the topmost aquifer is of decisive importance. This is true when considering the impact of agriculture (fertilizers and pesticides) and when assessing potential waste disposal sites, abandoned hazardous sites, etc. Determination of the protective effectiveness of the rock or superficial cover above an aquifer is car- 


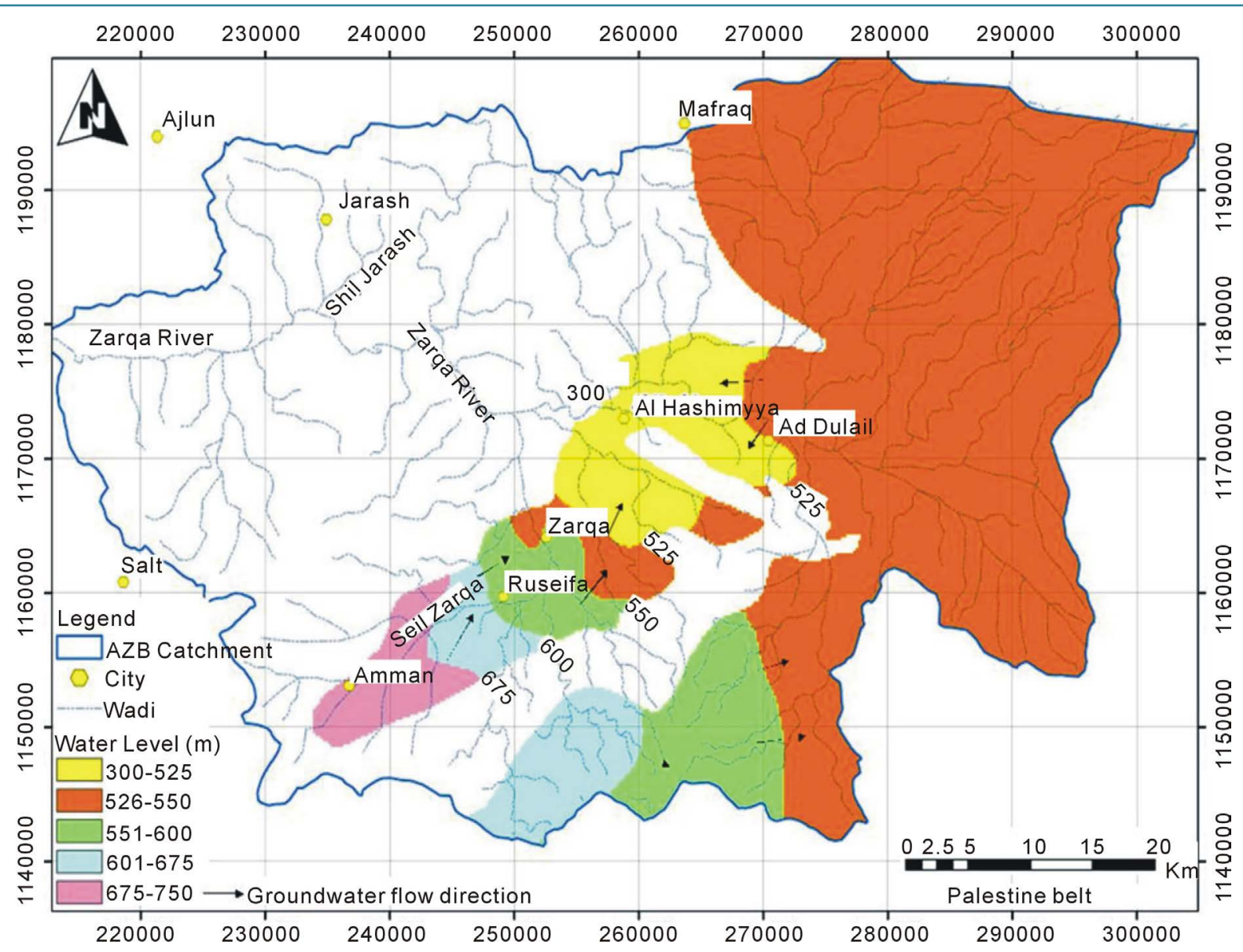

Figure 3. Groundwater contour map of B2/A7 Aquifer..

ried out to assess the risks to groundwater by pollutants moving through the soil and rock cover into the groundwater, and to represent the degree of risk on a map. The protective effectiveness "filtering effect" of the rock and soil cover depends on several factors, such as the compactness, mineralogical composition, porosity, content of organic matter, $\mathrm{pH}$, cation exchange capacity (CEC), the thickness of rock and soil cover, as well as the percolation rate and percolation velocity [8]. Moreover, groundwater pollutants may show different migration, sorption and degradation behavior, about which little is known. It would be necessary to develop special assessment methods for all pollutants, depending on their behavior in the groundwater systems, and then compile the corresponding hazard maps. In order to provide a practical method for the qualitative determination of the protective effectiveness of the rock and soil cover above an aquifer, an easy assessment scheme was devel-oped. Although it involves considerable simplification, it provides valuable information related to many pending problems. Starting from assessments at point sites based on existing data and without any costly determination of further parameters, the method allows the protective effectiveness of the rock and soil cover above an aquifer to be assessed over large areas. Thus, in many individual cases, time-consuming, detailed investigations and/or mapping can be avoided.

For preparation of the groundwater vulnerability map of the AZB area, the method proposed by the state geological surveys of Germany (GLA-method, [8]) was employed. This method is based on a rating system by which the overall protective effectiveness of the soil cover and unsaturated zone is calculated. It requires the following parameters:

Parameter 1: $S$ - soil effective field capacity

Parameter 2: $W$ - percolation rate (groundwater recharge)

Parameter 3: $\boldsymbol{R}$ - rock type

Parameter 4: $T$ - thickness of soil and rock cover above the aquifer 


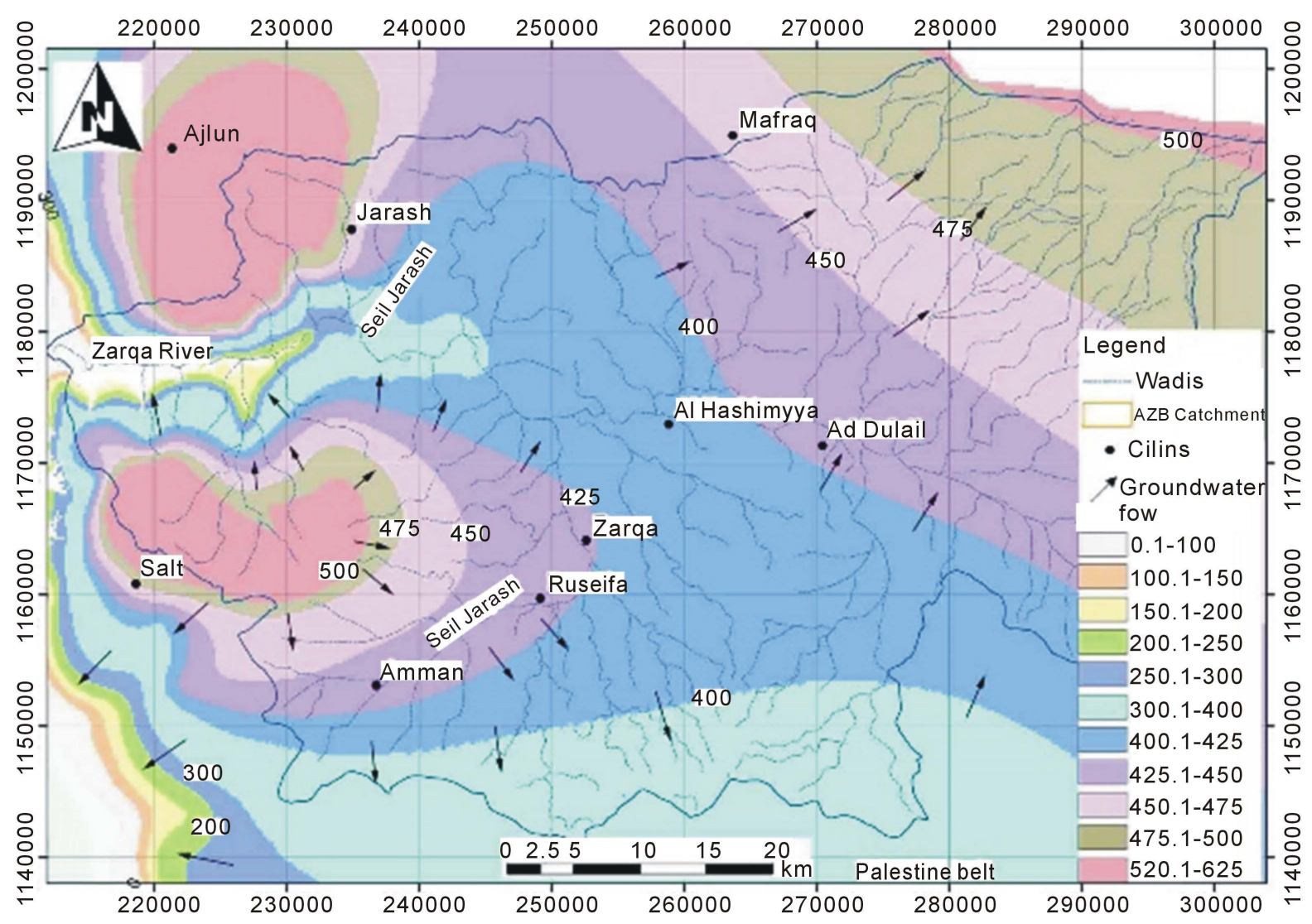

Figure 4. Groundwater contour map of kurnub aquifer.

\section{Parameter 5: $Q$ - bonus points for perched aquifer systems}

\section{Parameter 6: HP - bonus points for hydraulic pressure conditions}

The overall protective effectiveness (PT) is calculated using the following Equations (1)-(3):

$$
P T=P 1+P 2+Q+H P
$$

\section{P1-protective effectiveness of the soil cover:}

$$
P 1=S * W
$$

$P 2$ protective effectiveness of the unsaturated zone (sediments or hardrocks):

$$
P 2=W *(R 1 * T 1+R 2 * T 2+\cdots+R n * T n)
$$

For application in the semi-arid regions, the classification table for groundwater recharge (W-factor) was modified [22]. The spatial distribution of all above-mentioned parameters is sufficiently well known in Jordan from the following sources listed in Table 1. Groundwater vulnerability maps can easily be prepared using ArcGIS 10.1. For the vulnerability map of the Amman-Zarqa Basin an equal distant grid with a cell size of $50 \mathrm{~m}$ $\mathrm{X} 50 \mathrm{~m}$ was used. Such a cell size proved to be most suitable for both, data availability and scale of presentation. The AZB vulnerability map is intended for presentation at 1:50,000 scale.

\subsection{Parameter 1: Effective Field Capacity (eFC) (SFactor)}

Soils in AZB are characterized by low physical and chemical fertility since they are poorly aggregated and mostly calcareous with high gravel and stone contents. The high gravel content reduces the detachability of soil particles and allows macro-pore flow in between this makes the subsurface layers and groundwater potentially susceptible for contamination [26]. Soil thickness at the AZB varies from $15 \mathrm{~cm}$ to $1 \mathrm{~m}$ with minimum at the central and eastern parts of the AZB. For the soil system, the effective field capacity (eFC) is taken as a measure of the capacity of a soil to store plant-available water [27]. The effective field capacity of a soil depends mainly 


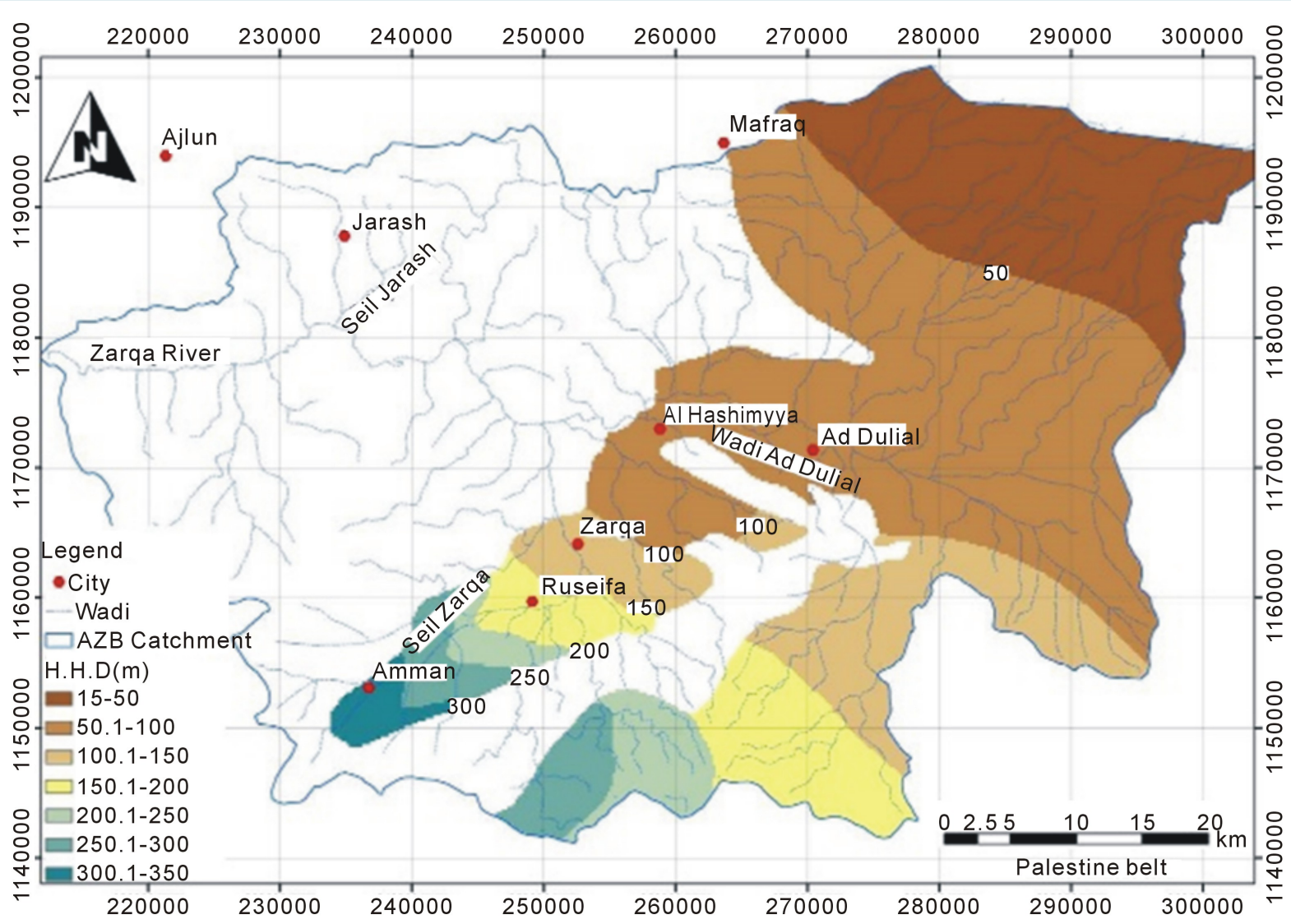

Figure 5. Hydraulic head difference (H.H.D) between B2/A7 Aquifer and Kurnub Aquifer.

Table 1. Sources of the parameters for this study.

\begin{tabular}{|c|c|c|}
\hline & Parameter & Method of Calculation \\
\hline $\mathbf{S}$ & 1-Soil Effective field capacity & $\begin{array}{l}\text { Laboratory measurement on soil samples using ceramic plate apparatus } \\
\text { with aid of national soil maps [23] [24] }\end{array}$ \\
\hline $\mathbf{W}$ & 2-Percolation rate (Recharge) & Field measurements and tests \\
\hline $\mathbf{R}$ & 3-Rock type & Structure contour maps [25], Natural Resources Authority (NRA) and field visits \\
\hline $\mathbf{T}$ & 4-Thickness & Natural Resources Authority Mapping reports (NRA) and field visits [25] \\
\hline $\mathbf{Q}$ & 5-Bonus points perched aquifer & Not relevant in study area \\
\hline HP & 6-Bonus points for hydraulic pressure conditions & Not relevant in study area (no areas with upward leakage) \\
\hline
\end{tabular}

on solid-water interfaces as grain size (soil texture), ped/pore, shape-size-continuity (soil structural pedality), degree of compaction and organic matter (mainly humus) content and is generally determined for the profile down to the effective rooting depth [28]. A soil water retention curve defines the relationship between volumetric water content $\Theta_{\mathrm{v}}\left[\mathrm{cm}^{3} \cdot \mathrm{cm}^{-3}\right]$ and soil matric potential $\Psi_{\mathrm{m}}$ [cm water column], where soil matric potential "suction power" is defined as the reduction in water potential to move from point to point within the soil system due to solid-water adsorption. Thus, $\Psi_{\mathrm{m}}$ is set to be a maximum of zero at saturation (i.e. when all pores are filled with water, $\Theta_{\mathrm{v}}=\Theta_{\mathrm{S}}$ ), while it is set to be negative at unsaturated conditions [29]. The $\Psi_{\mathrm{m}}$ is often expressed as the logarithm of the suction power in [cm], and then called the pF-value. Plant available water (effective field capacity) can be estimated by subtraction of the water content at two main points; the field capacityconsidered at 0.3 bar and wilting point at 15 bar (i.e. range between $\boldsymbol{p F}_{\text {values }}$ of 1.8 (field capacity) and 4.2 (wilting point)). The effective field capacity of the soil in the study area was obtained from measurements performed on 250 soil samples collected from the basin with the aid of soil maps [23] [24]. Samples were subjected to phys- ical and chemical analyses after being dried in glass house at the University of Jordan. In addition, soil 
samples textures were determined using pipette method [30]. Table 2 summarizes the different analyzed and measured parameters for the soil samples.

The eFC is then multiplied by the thickness of the horizon in decimeters [dm]. To simplify the calculation, the rooting depth is assumed to be constant at $10 \mathrm{dm}$. The total effective field capacity of a soil ( $\Sigma F C)$ is obtained by addition of the effective-field-capacity values calculated for each horizon down to $1 \mathrm{~m}$ depth (or to the water table if $<1 \mathrm{~m}$ below ground surface). For shallow soils, the effective field capacity of the substrate below the actual soil zone is assessed down to a depth of $1 \mathrm{~m}$ and included in the calculation.

The total effective field capacity is subdivided into 6 classes as in the Pedological Mapping Handbook. Each of these classes is given a number of points, a large number corresponding to a comparatively long residence time of the percolating water (Table 3).

Table 2. Summary of soil parameters.

\begin{tabular}{|c|c|c|c|c|}
\hline Parameter & Mean & Min. & Max. & Std. Dev. \\
\hline ECemS/cm & 4.56 & 0.84 & 15.53 & 3.58 \\
\hline pH-value & 8.08 & 7.60 & 8.47 & 0.21 \\
\hline $\mathrm{Ca}^{2+}(\mathrm{meq} / \mathrm{L})$ & 14.96 & 3.76 & 33.84 & 9.01 \\
\hline $\mathrm{Mg}^{2+}$ (meq/L) & 14.04 & 2.48 & 63.92 & 15.32 \\
\hline $\mathrm{Na}^{+}(\mathrm{meq} / \mathrm{L})$ & 13.02 & 1.53 & 47.54 & 11.53 \\
\hline $\mathrm{K}^{+}(\mathrm{meq} / \mathrm{L})$ & 3.15 & 0.53 & 9.90 & 2.53 \\
\hline $\mathrm{HCO}_{3}^{-} \quad(\mathrm{meq} / \mathrm{L})$ & 4.90 & 2.20 & 11.00 & 1.93 \\
\hline $\mathrm{CO}_{3}^{2-} \quad(\mathrm{meq} / \mathrm{L})$ & 0.04 & 0.00 & 1.00 & 0.19 \\
\hline $\mathrm{Cl}^{-}(\mathrm{meq} / \mathrm{L})$ & 22.78 & 5.00 & 72.96 & 18.19 \\
\hline $\mathrm{SO}_{4}^{2-} \quad(\mathrm{meq} / \mathrm{L})$ & 9.45 & 0.65 & 47.30 & 11.49 \\
\hline $\mathrm{N}-\mathrm{NO}_{3}(\mathrm{meq} / \mathrm{L})$ & 8.34 & 0.21 & 29.00 & 7.38 \\
\hline Total Nitrogen \% & 0.14 & 0.07 & 0.20 & 0.03 \\
\hline $\mathrm{CaCO}_{3} \%$ & 34.71 & 18.00 & 50.00 & 9.31 \\
\hline CEC meq/100g & 11.82 & 7.29 & 17.78 & 3.23 \\
\hline Exchangeable Na (meq/100g) & 1.14 & 0.40 & 1.86 & 0.46 \\
\hline ESP & 9.53 & 5.03 & 13.88 & 2.35 \\
\hline P-Olsenppm & 105.20 & 15.40 & 219.87 & 59.43 \\
\hline Available K ppm & 674.14 & 216.00 & 1310.00 & 217.98 \\
\hline Organic Matter \% & 1.86 & 1.12 & 2.51 & 0.36 \\
\hline Gypsum Content \% & 3.45 & 2.00 & 5.00 & 0.96 \\
\hline Active Lime \% & 11.24 & 6.00 & 18.00 & 3.44 \\
\hline B (Hot Water) ppm & 1.68 & 0.18 & 5.96 & 1.41 \\
\hline Cu DTPA ppm & 1.91 & 0.86 & 4.68 & 1.02 \\
\hline Fe DTPA ppm & 9.70 & 3.40 & 21.20 & 5.00 \\
\hline Zn DTPA ppm & 5.95 & 1.50 & 11.00 & 2.48 \\
\hline Mn DTPA ppm & 15.94 & 6.80 & 35.00 & 6.31 \\
\hline Cd DTPA ppm & 0.10 & 0.03 & 1.07 & 0.19 \\
\hline Co DTPA ppm & 0.25 & 0.18 & 0.38 & 0.06 \\
\hline Cr DTPA ppm & 0.05 & 0.02 & 0.08 & 0.02 \\
\hline Ni DTPA ppm & 0.78 & 0.33 & 1.40 & 0.23 \\
\hline Pb DTPA ppm & 0.96 & 0.63 & 1.46 & 0.23 \\
\hline pF(0.3) bar-pw\% & 25.41 & 15.20 & 31.00 & 4.14 \\
\hline $\mathrm{pF}(15.0)$ bar-pw\% & 16.46 & 7.90 & 21.70 & 3.17 \\
\hline Clay \% & 27.24 & 12.10 & 42.10 & 8.30 \\
\hline Silt \% & 52.50 & 28.50 & 68.50 & 10.32 \\
\hline Sand \% & 20.27 & 2.50 & 55.90 & 13.76 \\
\hline
\end{tabular}

DTPA: Diethylenetriaminepentaacetic Acid; ESP: Exchangeable Sodium Percentage; pF: Soil water retention. 


\subsection{Parameter 2: Percolation rate (W Factor)}

As far as possible, the available data on annual groundwater recharge from rainfall is used to determine the percolation factor $\mathrm{W}$ (Table 4). However, if the data is not available, a comparable figure can be determined by taking the difference between the annual rainfall $(\mathrm{N})$ and the potential evapotranspiration (ETp).

For this study, percolation rate (Recharge) was determined based on rainfall-recharge equations adopted from Margane et al. [31]. These equations were applied depending on outcropping formations in the study area. Figure 6 present the recharge $(\mathrm{mm} / \mathrm{y})$ while Table 5 shows the recharge $(\mathrm{mm} / \mathrm{y})$ and recharge value.

As presented in Figure 6, the groundwater recharge in AZB is below $100 \mathrm{~mm} / \mathrm{a}$. However, according to the German mapping approach, the highest value assigned for factor $\mathrm{W}$, would be 1.75 for a groundwater recharge of less than $100 \mathrm{~mm} / \mathrm{a}$ [8]. Therefore, a modified scale for the factor $\mathrm{W}$ was introduced which reflects the low amounts of groundwater recharge in the study area (Table 6). The final spatial distribution map for the W-Factor is presented in Figure 7.

The $\mathrm{W}$-factor was obtained using the recharge rates (Figure 6) presented in Table 6. Results show the spatial distribution of the natural protection of the respectively different aquifer systems in the AZB.

\subsection{Parameter 3: Rock Type Factor (R Factor)}

The protective effectiveness of the rock cover above the uppermost aquifers and below the soil, i.e. from a standard depth of $1 \mathrm{~m}$ below ground surface down to the water table is individually calculated for each bed and the points for all beds in the section are then added up. The protective effectiveness of the rock cover below the soil

Table 3. Assessment of soils on the basis of effective field capacity (eFC) (number of points = S).

\begin{tabular}{cc}
\hline SeFC $[\mathbf{m m}]$ & S \\
\hline down to 1.0 m depth & 750 \\
$>250$ & 500 \\
$>200-250$ & 250 \\
$>140-200$ & 125 \\
$>90-140$ & 50 \\
$>50-90$ & 10 \\
$<50$ & 10 \\
\hline
\end{tabular}

Table 4. Percolation rates and the corresponding factor (W), based on the actual groundwater recharge (GWR) or an alternative figure given by ETp.

\begin{tabular}{ccc}
\hline GWR [mm/a] & ETp. [mm/a] & Factor W \\
\hline$<100$ & & 1.75 \\
$>100-200$ & $<100$ & 1.5 \\
$>200-300$ & $>100-200$ & 1.25 \\
$>300-400$ & $>200-300$ & 1.0 \\
$>400$ & $>300-400$ & 0.75 \\
\hline
\end{tabular}

Table 5. Groundwater recharge to the geological units in the AZB [31].

\begin{tabular}{cccc}
\hline Hydrogeological Unit & Percentage of Rainfall & Size $\left[\mathbf{k m}^{2}\right]$ & Total Groundwater Recharge to Unit in AZB [MCM/a] \\
\hline Basalt & 15 & 760.0 & 21.4 \\
B3 & 0 & 305.5 & 0 \\
A7/2 & 15 & 1570.2 & 48.2 \\
A1/6 & 7.5 & 744.7 & 26.5 \\
Kurnub & 7.5 & 160.0 & 6.4 \\
Zarqa & 0 & 25.3 & 0 \\
Total & & $\mathbf{3 5 6 6}$ & $\mathbf{1 0 2 . 5}$ \\
\hline
\end{tabular}




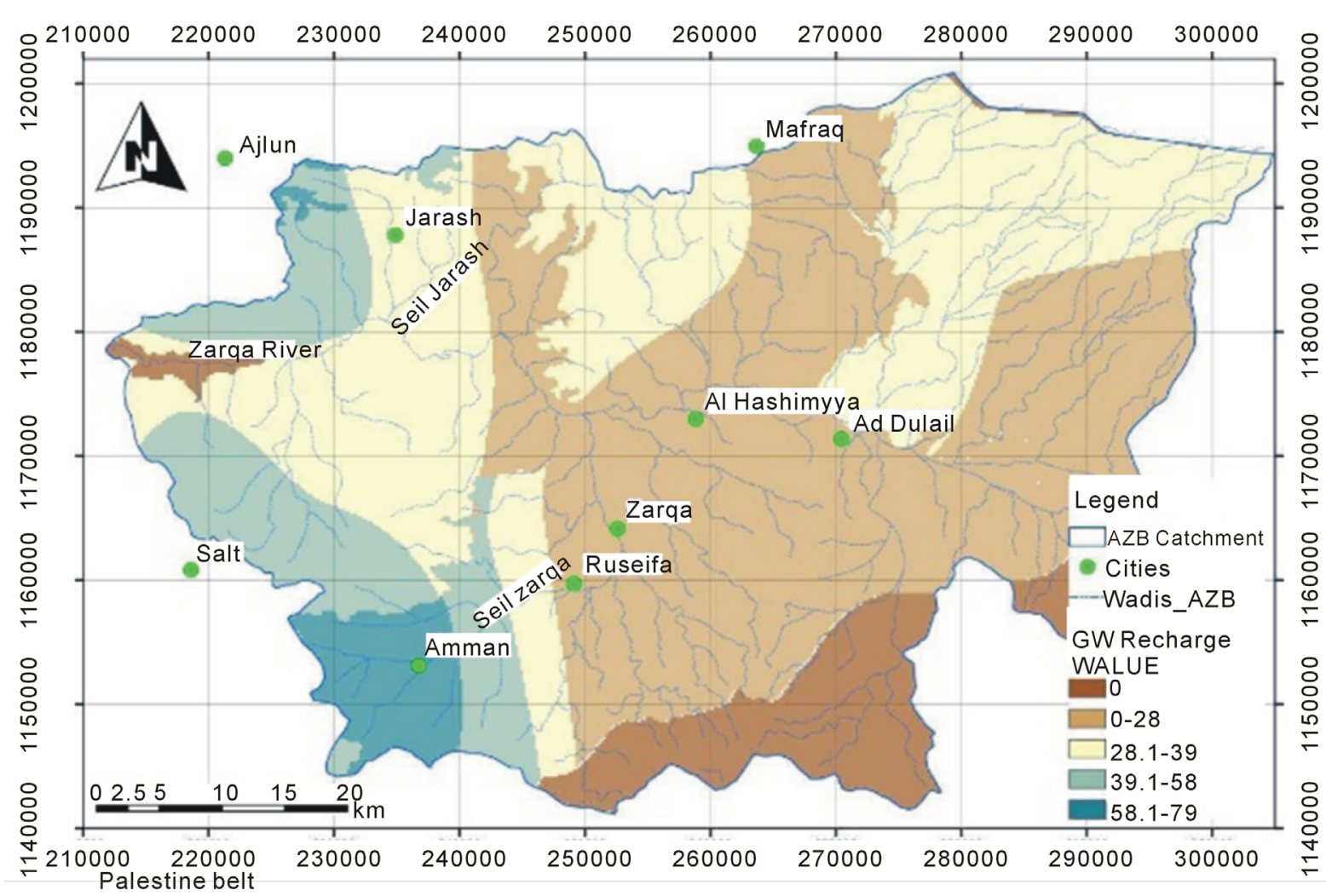

Figure 6. Groundwater recharge.

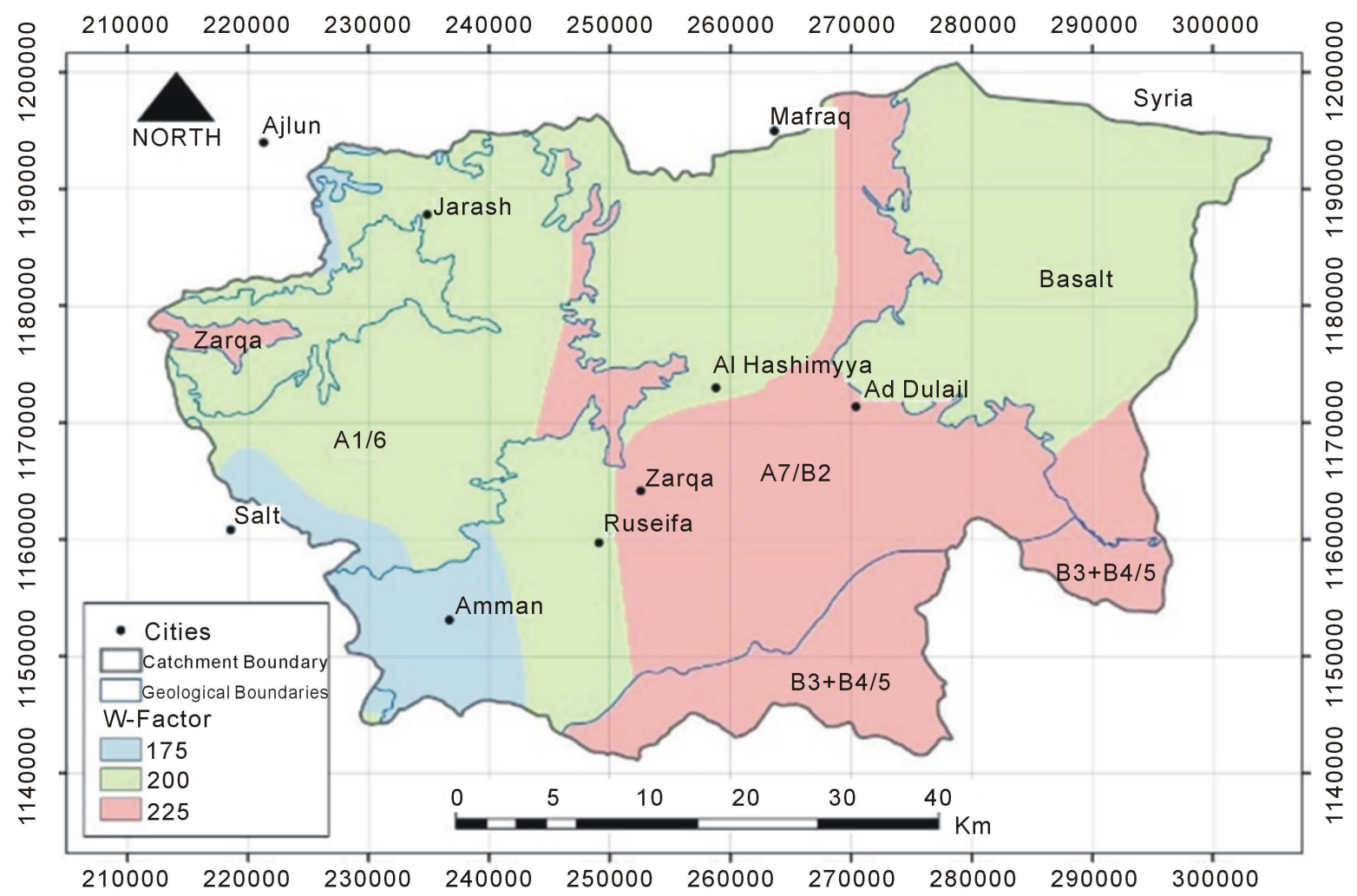

Figure 7. Spatial distribution of W-Factor (groundwater recharge). 
depends on various parameters, which are assessed according to their rock type (R). Due to their fundamentally different geohydraulic rock properties, unconsolidated and consolidated rocks are assessed separately.

In the case of unconsolidated rocks, the residence time is derived via the cation exchange capacity (CEC), since both of these factors depend directly on the proportion of fine-grained material present. In addition, the solid rocks, in spite of their mostly very low intrinsic permeability, often show high permeability due to jointing and/or karstification, and thus comparatively short residence times for percolating water. Therefore, the number of points $(R)$ is determined as the product of the rock type $(O)$ that reflects the low intrinsic permeability of the rock multiplied by factor (F) reflecting the presence of joints, karst cavities as explained in Table 7. Based on Table 7, the rock and structure factors that have been used for the preparation of the P2 map are listed in Table 8.

\subsection{Parameter 4: Thickness of the Soil and Rock Cover (T Factor)}

The distance covered by percolating water (assuming vertical percolation), i.e. the thickness of the soil and rock above the topmost aquifer, affects the residence time and thus the time that percolating water is exposed to mechanical, physico-chemical, and microbial processes. In assessing the protective effectiveness, the thickness of each bed in meters is used as a factor in the calculation. The thicknesses of the strata were calculated by using different stratigraphical maps as GIS layers.

\subsection{Parameter 5: Perched Aquifer Systems (Q Factor)}

A perched aquifer may prevent the migration of pollutants to greater depths and/or may prevent or delay contamination of the main aquifer system. This protection is most effective where natural springs occur. A bonus (Q) of 500 points is added for each perched aquifer with springs. However, this factor was not relevant in study area.

Table 6. Modification of factor W (Percolation Rate).

\begin{tabular}{cc}
\hline Groundwater Recharge [mm/a] & Factor W \\
\hline$>100-200$ & 1.5 \\
$>50-100$ & 1.75 \\
$>25-50$ & 2 \\
$\leq 25$ & 2.25 \\
\hline
\end{tabular}

Table 7. Assessment of consolidated rocks (number of points $=\mathrm{R}_{\mathrm{s}}$ ) = product of points for rock type (O) and factor for joints, karst cavities, etc. $(F)$, i.e. $\mathrm{R}_{\mathrm{s}}=\mathrm{O} \times \mathrm{F}$.

\begin{tabular}{ccc}
\hline Rock type & O & Structure \\
\hline $\begin{array}{c}\text { clay stone, slate, marlstone, siltstone } \\
\text { sandstone, quartzite, volcanic rock, plutonic rock, } \\
\text { metamorphic rock }\end{array}$ & 20 & non-jointed \\
$\begin{array}{c}\text { porous sandstone, porous volcanic rock (e.g. tuff) } \\
\text { conglomerate, breccia, limestone, tufaceous limestone, } \\
\text { dolomitic rock, gypsum rock }\end{array}$ & 15 & slighted \\
\hline
\end{tabular}

Table 8. Rock factors and structure factors used.

\begin{tabular}{cccc}
\hline Formation & Rock Factor & Structure Factor \\
\hline Basalt & 10 & 0.3 \\
B4/5 & 5 & 0.3 & 4 \\
B3 & 20 & 0.3 \\
B2/A7 & 5 & 0.3 \\
A1/6 & 10 & 0.3 \\
Kurnub & 10 & 0.3 \\
\hline
\end{tabular}




\subsection{Parameter 6: Hydraulic Pressure Conditions (HP Factor)}

The hydraulic pressure conditions depend, among other things, on the lithology of the soil and rock cover above the aquifer, which has already been taken into account by the points awarded for each rock type. However, permanent artesian conditions are particularly effective as a natural protection against percolation of contaminated water into the aquifer. Therefore, a bonus (HP) of 1500 points is given in this case. In the study area this factor is not relevant (no areas with upward leakage).

\subsection{Determination of the Overall Protective Effectiveness $\left(P_{t}\right)$}

To determine the overall protective effectiveness $\left(\mathrm{P}_{\mathrm{t}}\right)$ of the soil and rock cover above the topmost aquifer, the following procedure is adopted: initially, the protective efficiencies of the soil $\left(\mathbf{P}_{1}\right)$ and the rock cover $\left(\mathbf{P}_{2}\right)$ are calculated separately.

\subsubsection{Soil Cover $\left(\mathrm{P}_{1}\right)$}

The number of points (S) given for the effective field capacity (eFC) of the soil from Table 1 is multiplied by factor W, which represents the percolation rate (see Table 2), Equation (2).

The final P1 map, describing the protective effectiveness of the soil cover is present in Figure 8.

\subsubsection{Rock Cover $\left(\mathrm{P}_{2}\right)$}

Each individual bed in the rock cover below the soil (below one meter depth) and above the aquifer is assessed separately: in the case of unconsolidated rock (no. of points $=\mathbf{R}_{\mathbf{u}}$ ) using Table 3 and in the case of solid rock (no. of points $=\mathbf{R}_{\mathrm{s}}$ ) using Table 5; the number of points is then multiplied by the stratigraphic thickness in meters (factor $\mathbf{T}$ ). The sum of all points for individual rock units, i.e. the entire section from $1 \mathrm{~m}$ below the surface to the water table (to the top of the aquifer in the case of a confined aquifer) gives a figure representing the protective effectiveness of the rock cover below the soil. This figure, as in the case of the soil cover, is multiplied by factor $\mathbf{W}$ (from Table 2), which represents the percolation rate. The number of points $\left(\mathbf{P}_{2}\right)$ representing the protective effectiveness of the rock cover below the soil is calculated as by the flowing Equation (3) The $\mathbf{P}_{2}$ map which describes the protective effectiveness of the rock cover above the aquifer is present in Figure 9.

\section{Hazard Analysis and Mapping}

A hazard map for the study area was prepared using a 7-step work plan (Figure 10), starting from an Inventory of Hazards and leading to the eventual production of Hazard Map.

\subsection{Step 1: Definition and Inventory of Hazards}

In the context of groundwater contamination, a hazard is defined as a potential source of contamination resulting from human activities taking place mainly at the land surface. A hazard assessment was conducted through identifying the potential degree of harmfulness for each type of hazard. This was determined by both the toxicity and the quantity of harmful substances, which may be released as a result of a contamination event [3].

Hazards were classified according to the type of land use (Level I) and the main source (Level II) Level I was based on a local and regional scale distinguishes between three main categories; i.e. infrastructural, industrial and agricultural activities (Table 9). Level II categories was based on main source (i.e. solid or liquid contaminants) of possible groundwater contamination, or else refer to types of industrial or agricultural activities with their corresponding spectrum of possible pollutants. Cost 620 [3] presented a detailed table (Table10) for most of the hazards that may exist in any area with their weighting values.

\subsection{Step 2: Hazard Data Requirements}

The potential degree of harmfulness for each type of hazard was assessed through acquiring information on process or nature of activity, type of harmful substances, amount of substances which can be released and age and status of installations and plants. The collected information for each type of hazard were grouped according to the identification of the nature of the activity, localization of the activity by topographic coordinates, characterization and quantification of the solid and liquid waste production. 


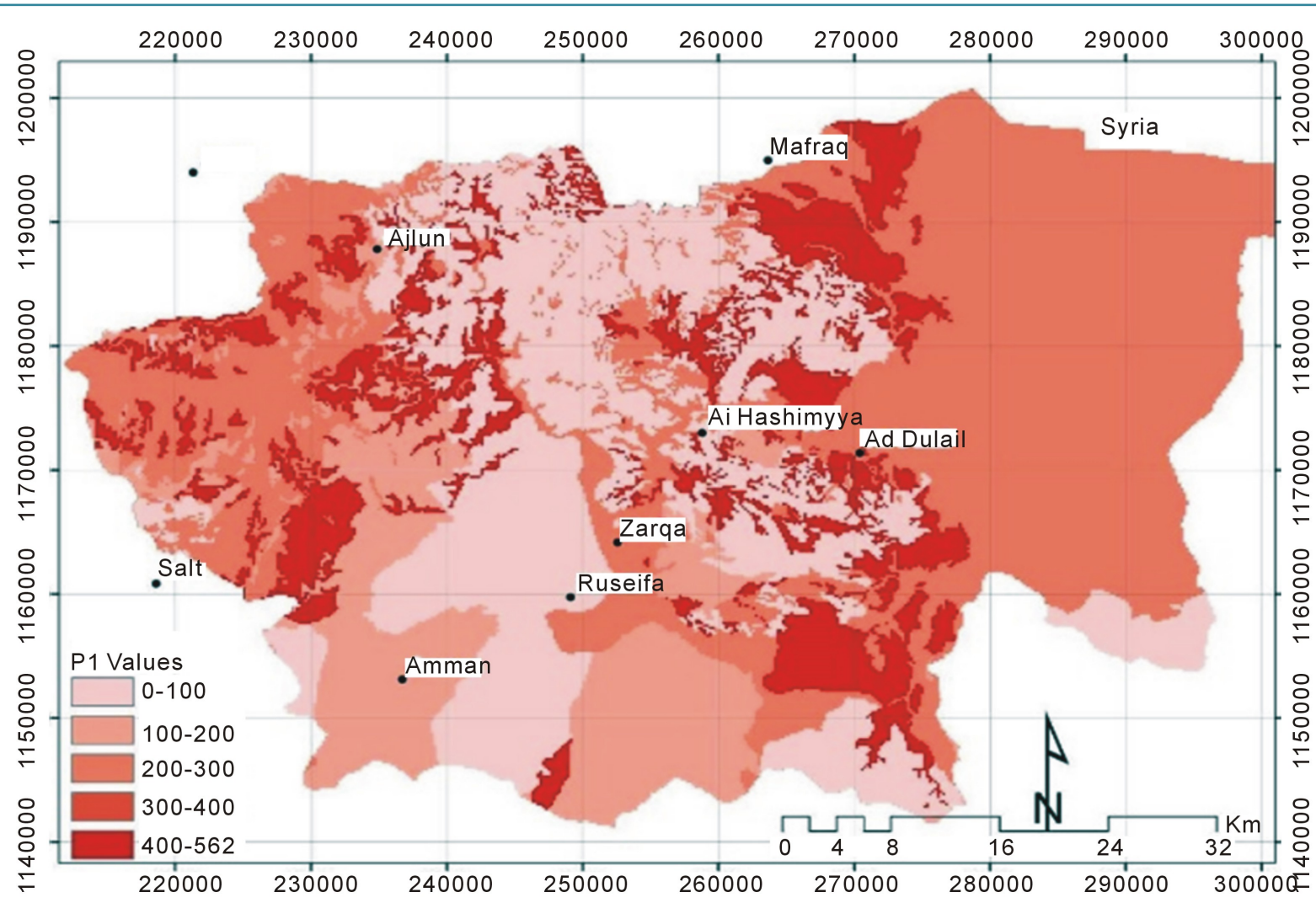

Figure 8. P1 Map showing the protective effectiveness of the soil covers.

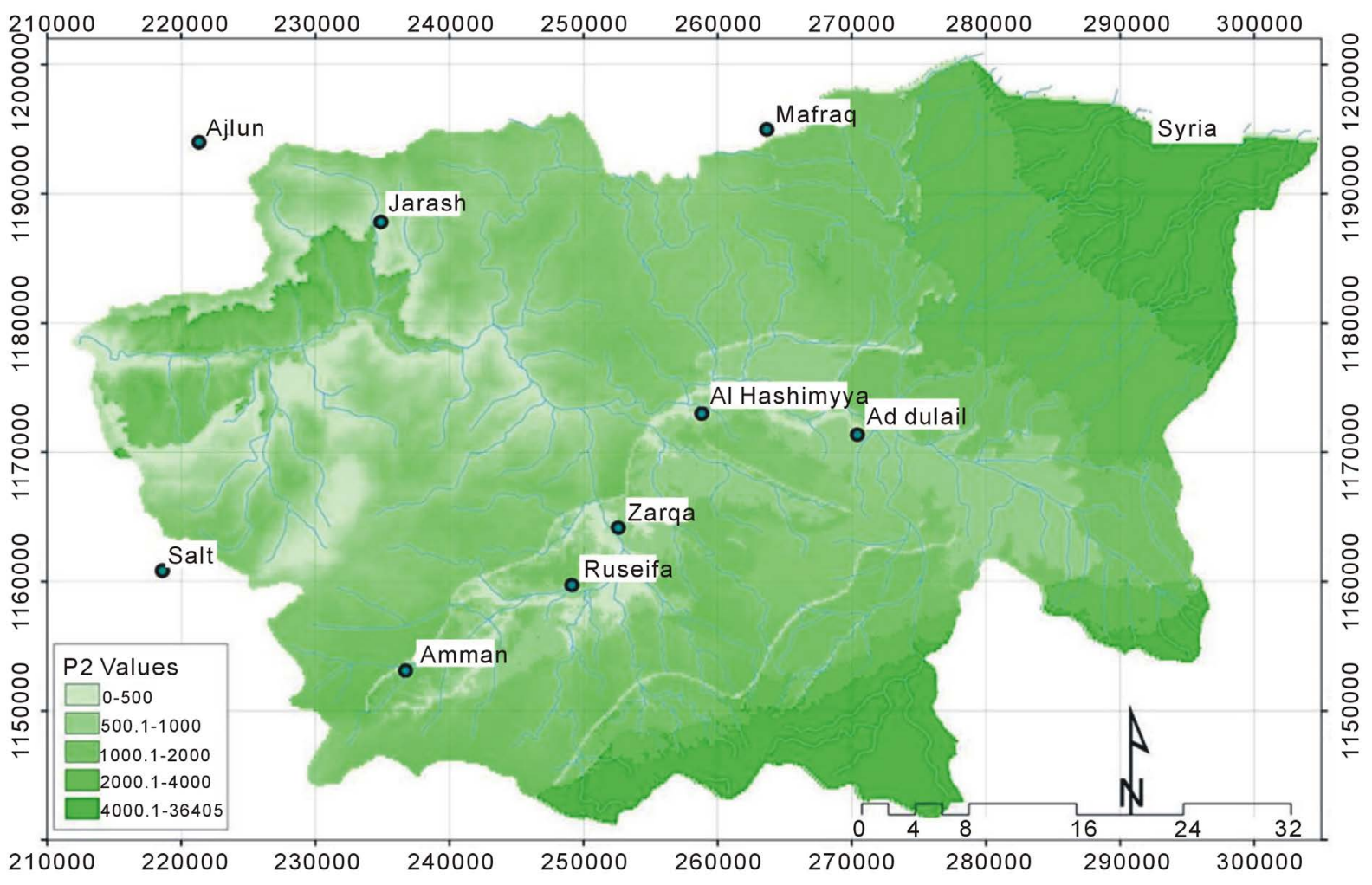

Figure 9. P2 Map showing the protective effectiveness of the rock covers. 


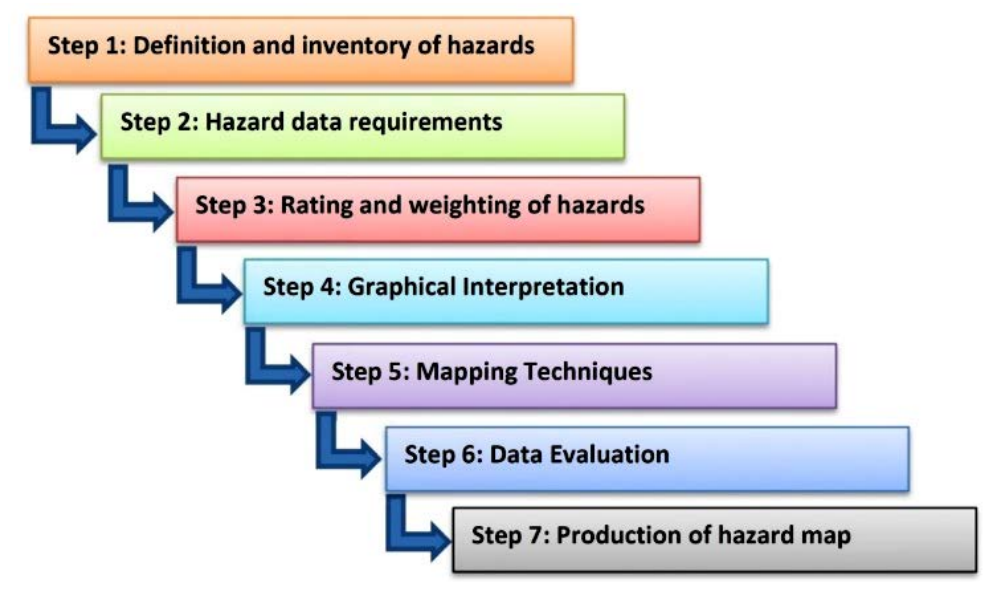

Figure 10. Work plan for the preparation of hazard maps [3].

Table 9. Classification of hazards for groundwater protection purposes [3].

\begin{tabular}{|c|c|c|}
\hline Number & Number Level I Categories of Hazards & Level II Categories of Hazards \\
\hline 1 & \multirow{7}{*}{ Infrastructural development } & \\
\hline 1.1 & & waste water \\
\hline 1.2 & & municipal waste \\
\hline 1.3 & & fuels \\
\hline 1.4 & & transport and traffic \\
\hline 1.5 & & recreational facilities \\
\hline 1.6 & & diverse hazards \\
\hline 2 & \multirow{8}{*}{ Industrial activities } & \\
\hline 2.1 & & mining (in operation and abandoned) \\
\hline 2.2 & & excavation sites \\
\hline 2.3 & & oil and gas exploration \\
\hline 2.4 & & industrial plants (non-mining) \\
\hline 2.5 & & power plants \\
\hline 2.6 & & industrial storage \\
\hline 2.7 & & diverting and treatment of waste water \\
\hline 3 & \multirow{3}{*}{ Livestock and agriculture } & \\
\hline 3.1 & & livestock \\
\hline 3.2 & & agriculture \\
\hline
\end{tabular}

\subsection{Step 3: Rating and Weighting of Hazards}

Table 10 determines the weighting coefficient or the "harmfulness of a hazard to groundwater $(\boldsymbol{H})$ " varying between 10 and 100. For a comparison between hazards of the same type, all the different factors influencing the degree of harmfulness were considered. According to the general definition of the hazard categories, the hazardous substances involved within each individual category are more or less the same or can be considered to be from the same group. Therefore the differences in harmfulness within each hazard category were mainly due to the variable quantity $\left(\boldsymbol{Q}_{n}\right)$ of harmful substances, which can be released and further seep into the underground. A ranking factor between 0.8 and 1.2 was then used in order to indicate low or high amounts, respectively, of toxic substances compared with the general average.

To avoid time consuming, a reduction factor $\mathrm{R}_{\mathrm{f}}$ was implemented to assess the probability for a contamination event to occur. If no information on the above mentioned factors is available, then $R_{f}=1$. Otherwise, positive information concerning the reduction of the likelihood can be used to reduce the hazard index. The generated 
Table 10. Hazard weighting values [3].

\begin{tabular}{|c|c|c|}
\hline No. & Hazards & Weighting value \\
\hline \multirow[t]{4}{*}{1} & Infrastructural development & \\
\hline & Waste water & \\
\hline & Urbanization (leaking sewer pipes and sewer systems) & 35 \\
\hline & Urbanization without sewer systems & 70 \\
\hline \multirow[t]{6}{*}{1.1} & Detached houses without sewer systems & 45 \\
\hline & Septic tank, cesspool, latrine & 45 \\
\hline & Runoff from paved surfaces & 25 \\
\hline & Waste water discharge into surface water course & 45 \\
\hline & Municipal waste & \\
\hline & Garbage dump, rubbish bin, litter bin & 40 \\
\hline \multirow{5}{*}{1.2} & Waste loading station and scrap yard & 40 \\
\hline & Sanitary landfill & 50 \\
\hline & Spoils and building rubble depository & 35 \\
\hline & Sludge from treatment plants & 35 \\
\hline & Fuels & \\
\hline \multirow[t]{3}{*}{1.3} & Storage tank, above ground & 50 \\
\hline & Storage tank, underground & 55 \\
\hline & Transport and traffic & \\
\hline \multirow[t]{2}{*}{1.4} & Road, unsecured & 40 \\
\hline & Road tunnel, unsecured & 40 \\
\hline \multirow{2}{*}{1.5} & Recreational facilities & \\
\hline & Tourist urbanization & 30 \\
\hline \multirow{2}{*}{1.6} & Diverse hazards & \\
\hline & Animal burial & 35 \\
\hline 2 & Industrial activities & \\
\hline \multirow{3}{*}{2.1} & Mining (in operation and abandoned) & \\
\hline & Mining of salt & 60 \\
\hline & Excavation sites & \\
\hline \multirow[t]{3}{*}{2.2} & Excavation and embankment for development & 10 \\
\hline & Gravel and sand pit & 30 \\
\hline & Oil and gas exploitation & \\
\hline \multirow{5}{*}{2.3} & Production wells & 40 \\
\hline & Reinjection wells & 70 \\
\hline & Loading station & 55 \\
\hline & Industrial plants (none mining) & \\
\hline & Iron and steel works & 40 \\
\hline \multirow{4}{*}{2.4} & Chemical factory & 65 \\
\hline & Leather tannery & 70 \\
\hline & Oil refinery & 85 \\
\hline & Food industry & 45 \\
\hline \multirow{3}{*}{2.5} & Power plants & \\
\hline & Gasworks & 60 \\
\hline & Industrial storage & \\
\hline \multirow[t]{2}{*}{2.6} & Stock piles of raw materials and chemical & 60 \\
\hline & Containers for hazardous substances & 70 \\
\hline
\end{tabular}


Continued

\begin{tabular}{|c|c|c|}
\hline & Diverting and treatment for waste water & \\
\hline \multirow{3}{*}{2.7} & Waste water pipelines & 65 \\
\hline & Surface impoundment for industrial waste water & 65 \\
\hline & Discharge of treatment plants & 40 \\
\hline \multirow[t]{2}{*}{3} & Livestock and Agriculture & \\
\hline & Livestock & \\
\hline \multirow[t]{3}{*}{3.1} & Animal barn & 30 \\
\hline & Factory farm & 30 \\
\hline & Agriculture & \\
\hline \multirow[t]{2}{*}{3.2} & Open silage (field) & 25 \\
\hline & Stockpiles of fertilizers and pesticides & 40 \\
\hline
\end{tabular}

hazard index (HI) describing the degree of harmfulness of each hazard was then calculated according to Equation (4):

$$
H I=H * Q_{n} * R_{f}
$$

where by $\boldsymbol{H I}$ is the hazard index, $\boldsymbol{H}$ is the weighting value of each hazard as assigned in Table $\mathbf{1 0}, \boldsymbol{Q}_{\boldsymbol{n}}$ is the ranking factor $(0.8-1.2)$ and $\boldsymbol{R}_{f}$ the reduction factor $(0.0-1.0)$. The possible range of the hazard index $H I$ runs from 0 to 120 scores.

\subsection{Step 4: Production of Hazard Map}

The graphical interpretation map of hazard data was generated using a Geographic Information System (GIS) to show the hazard spatial behavior including their location and extent (size, shape). Table 11 summarizes the color patterns implemented to represent the potential degree of harmfulness of the different hazards as assigned according to the resulting hazard index.

The vulnerability map of the AZB can be classified as high to very high vulnerability (or low protective effectiveness) in the area between Amman and Zarqa, as well as the Dhulail-Hallabat area (Figure 11). It becomes low to very low in the area where the B2/A7 aquifer is covered by a sufficient thickness of the Muwaqqar Chalk Marl Formation (B3) which acts as aquiclude and/or depth to groundwater is rather high. It is generally better in the areas covered by basalt, compared to those where B2/A7 is at outcrop, due to the higher retention capacity of the basalt.

\section{Results and Discussion}

\section{Vulnerability Map}

The final protective effectiveness coefficient $\left(\mathbf{P}_{\mathbf{t}}\right)$ map for the entire soil and rock cover above the aquifer is calculated as the sum of $\mathbf{P}_{\mathbf{1}}$ and $\mathbf{P}_{\mathbf{2}}$ and present in Figure 11. In addition, the vulnerability map was classified into protective effectiveness according to Table 12. Five classes of protective effectiveness are shown, based on the above coefficient, and for which the ranges of the residence times of percolating water in the soil and rock cover above the aquifer are given.

The Kurnub aquifer, which consists of thick layers of marly facies, is generally well protected in the central and eastern parts of the AZB. In addition, the presence of the silty, clayey intercalations will decrease its permeability; this leads to a protection in its outcrop areas. However, it must be taken into consideration that the Kurnub aquifer is also recharged by infiltrating surface water from the Zarqa River, which is highly polluted due to the industrial activities along the river.

The groundwater vulnerability map of the B2/A7 aquifer shows that this aquifer can be easily contaminated in most parts of the AZB. Only the areas, where the B2/A7 aquifer is covered with B3, provide the opportunity for locating sites which are potentially hazardous to groundwater, such as waste disposals and industries, as is the case e.g. some $20 \mathrm{~km}$ east of Amman. Most favorable are those areas where groundwater flow is directed not towards the Dhulail-Hallabat area but rather to Azraq. 
Table 11. Hazard index and hazard index classes [3].

\begin{tabular}{cccc}
\hline Hazard index & Hazard index class & Hazard level & Color \\
$0-24$ & 1 & No or very low & Blue \\
$>24-48$ & 2 & Low & Green \\
$>48-72$ & 3 & Moderate & Yellow \\
$>72-96$ & 4 & High & Orange \\
$>96-120$ & 5 & Very high & Red \\
\hline
\end{tabular}

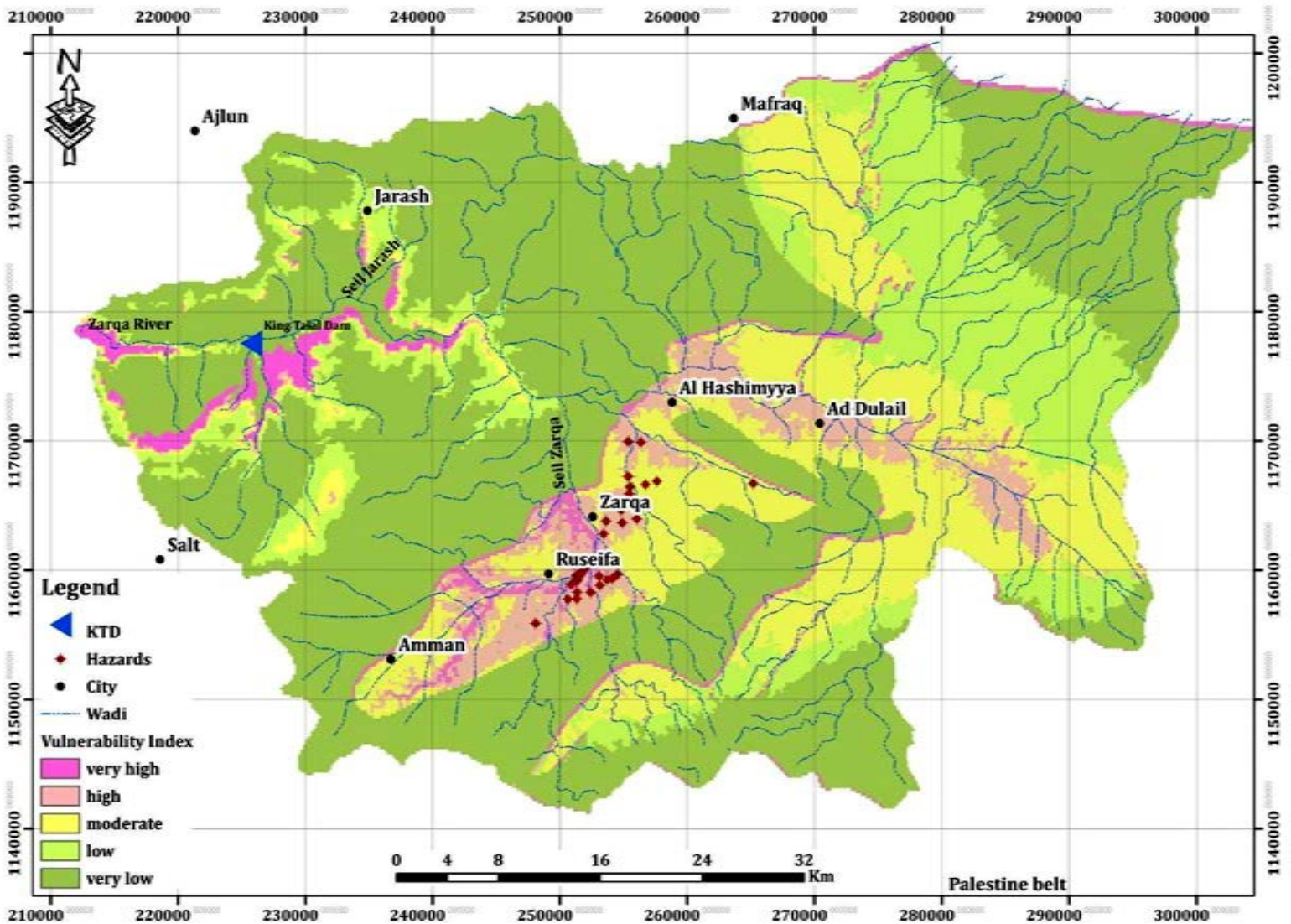

Figure 11. Groundwater vulnerability map $\left(\mathrm{p}_{\mathrm{t}}\right)$ hazard map.

Table 12. Classes of overall protective effectiveness.

\begin{tabular}{ccc}
\hline Overall protective effectiveness & Total points $\mathbf{P}_{\mathbf{t}}$ & $\begin{array}{c}\text { Approximate residence time of percolating water in the soil } \\
\text { and rock cover above the aquifer }\end{array}$ \\
\hline very high & $>4000$ & $>25$ year \\
high & $>2000-4000$ & $10-25$ years \\
moderate & $>1000-2000$ & $3-10$ years \\
low & $500-1000$ & several months to about 3 years \\
very low & 500 & a few days to about 1 year, in karstic rock often less \\
\hline
\end{tabular}

The highly vulnerable part of the area between Amman and Zarqa accommodates a considerable number of in dustries, which are potentially hazardous to groundwater. These pollution point sources are the pharmaceutical, dairy, textile, detergents, soft drink, stone cutting, oil refinery; thermal power plant; Ruseifa waste disposal (former phosphate mine; now closed); industrial free zone; tannery; iron steel company; industrial paper company; scrap yards for cars; and numerous military facilities. So far, these industrial enterprises do not dispose- 
suitable sewage from treatment facilities, as obliged by-law. These industries are located near the Seil Zarqa (River) and it is not known whether wastewater is discharged into the river or rather into the municipal wastewater collectors. Furthermore, several governmental wells within this area are still used for drinking purposes. Due to the high vulnerability of the aquifer, these wells have considerable pollution risk. On the other hand, olive trees are a very important cultivated product in the AZB. There are about 12 Olive mills existed in Jarash District. The olive mills start working during the rainy season from October up to December which increases the risk of groundwater pollution, especially knowing that most of these olive mills discharge their effluents (Zebar) directly into the major Wadis. The disposal is considered an urgent ecological problem that deteriorates the environment in the Jarash district. The generated hazard map for the study area shows that most of the basin is considered of low class (Figure 12).

On the other hand, some areas are set high while few points are set very high representing few industrial points of hazardous pollution. The type of hazards and their corresponding degree of harmfulness may partly change in the future because of infrastructure development that is being planned at the moment.

To show the effect of the leachate water from these point source contaminations on groundwater; 65 wellsclose to the areas were assigned as high risk areas for contaminations, have been sampled and analyzed for their constituents. Nitrate and selenium were monitored in these wells for two years. Results show a gradual increase in their concentrations over the years. Figures 13 and 14 depict the nitrate and selenium concentrations in the B2/A7 aquifer. It is clear that the hazardous points in the area have a great influence on the deterioration of groundwater quality of the aquifer.

\section{Conclusion}

The application of the German method GLA to groundwater vulnerability assessment in AZB provide valuable information, which can help define the land use classification and its potential role in groundwater management.

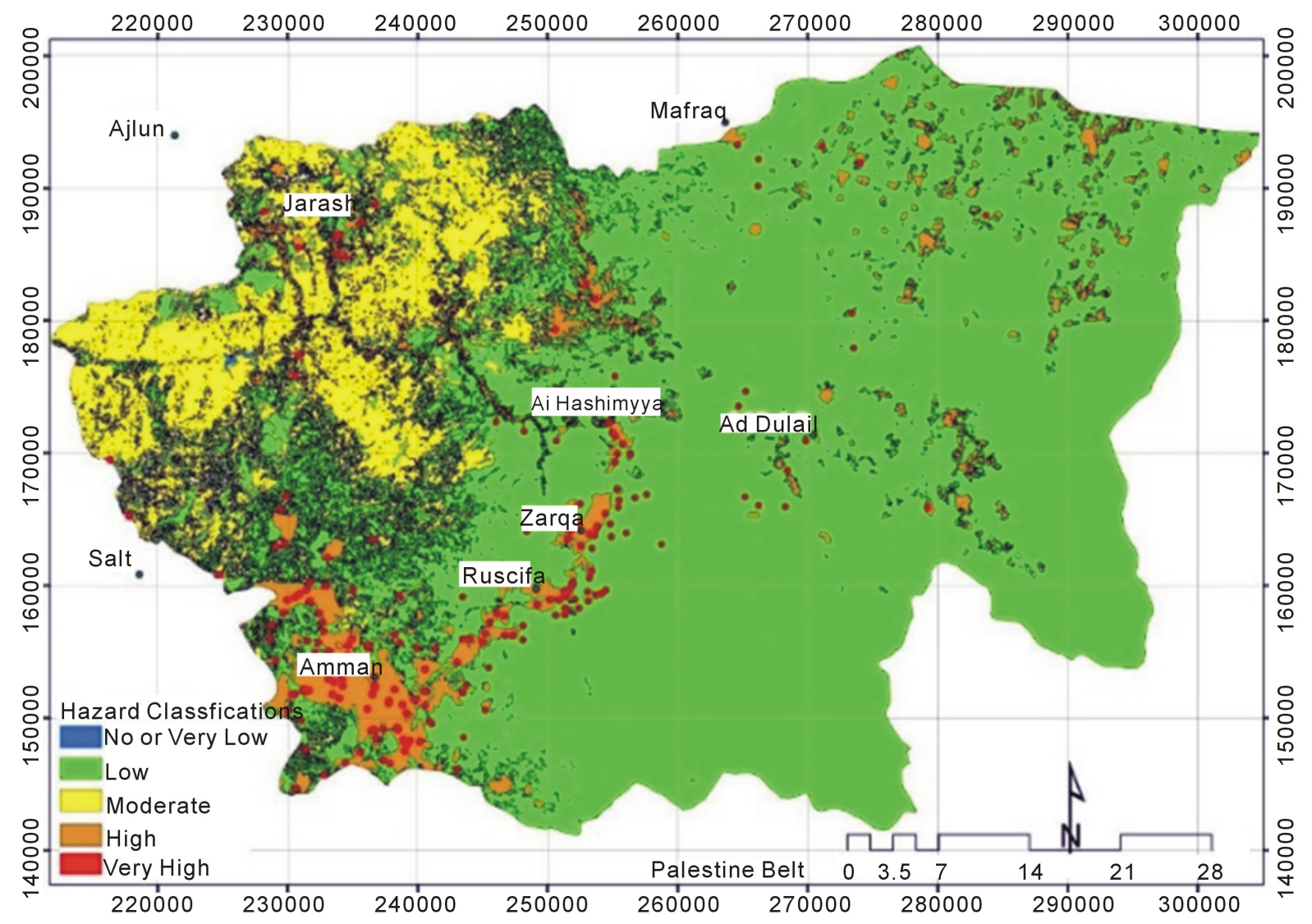

Figure 12. Classified hazard index map for AZB. 


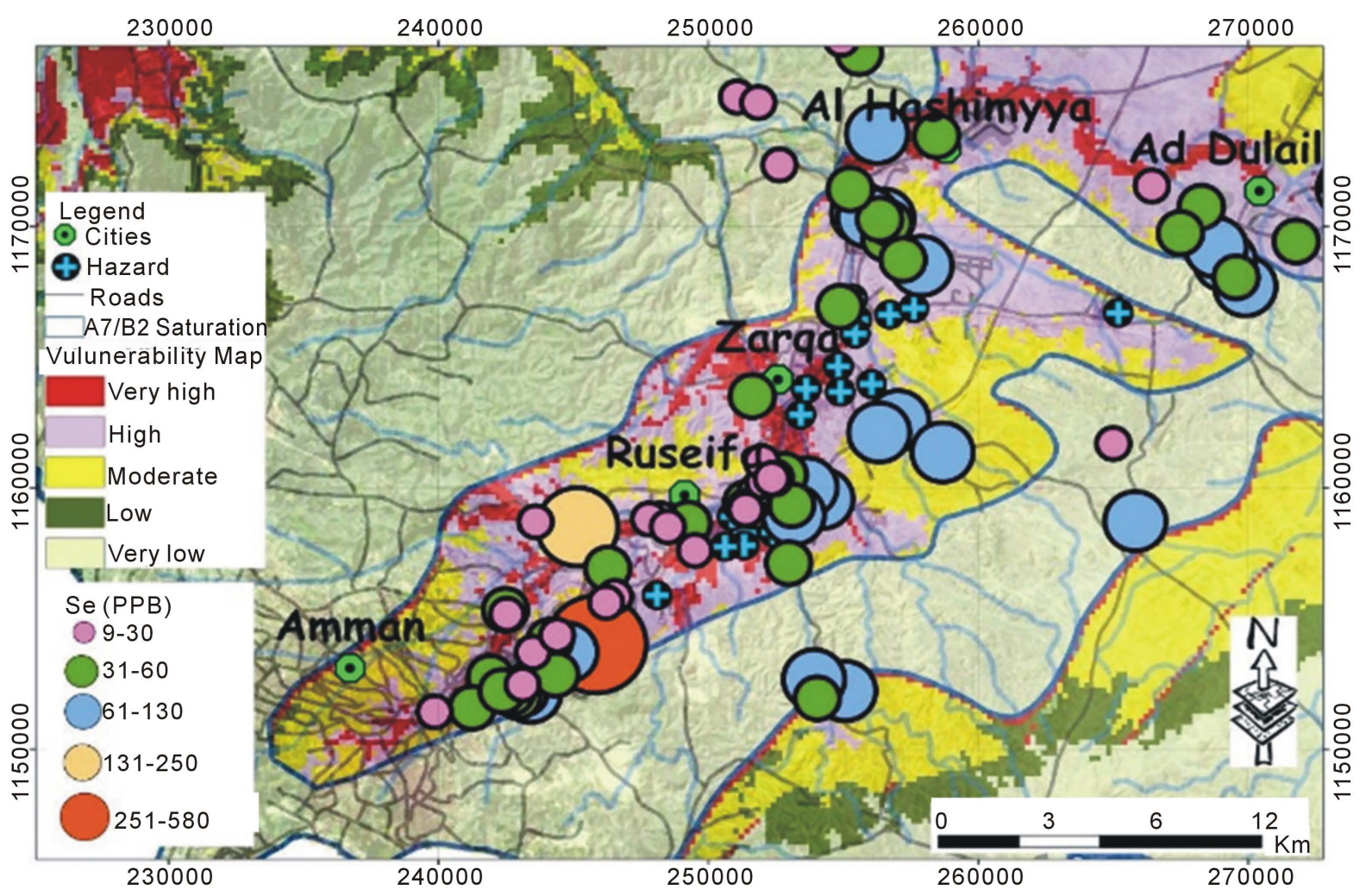

Figure 13. Selenium content in the B2/A7 aquifer in the central part of AZB.

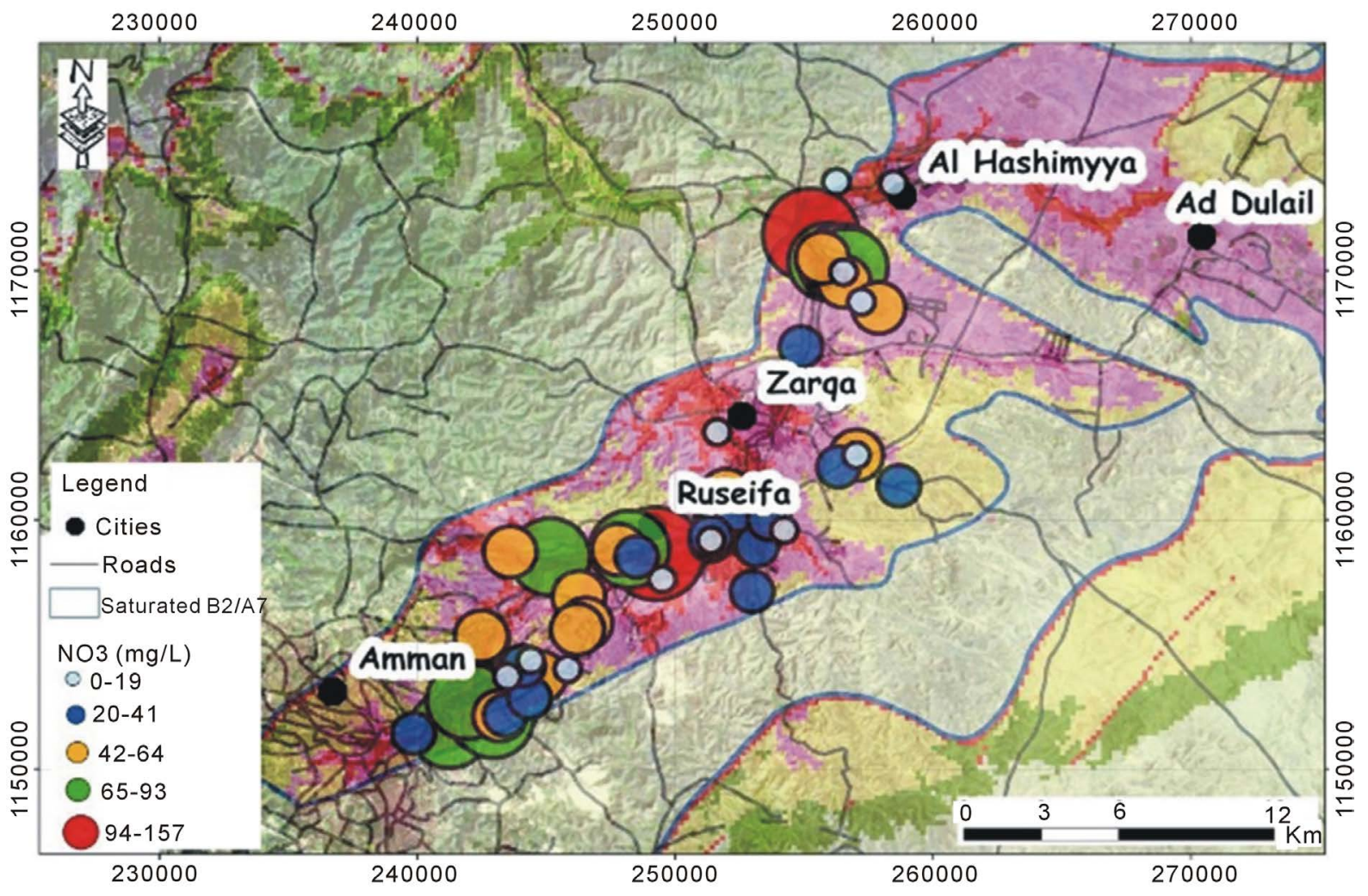

Figure 14. Nitrate concentrations in the B2/A7 aquifer in the central part of AZB. 
The generated vulnerability map can assist in the implementation of land use planning and groundwater management strategies to prevent degradation of groundwater quality. Large areas in the AZB can be classified as low risk or very low risk depending on the pollution source from the absence of pollution hazards and also from low vulnerabilities. These areas could consequently be interesting for future development as they are preferable in the context of ground water protection. New land use developments can easily be checked for problematic risk levels by constructing potential risk maps, also at a detailed scale, to assess the risk to groundwater contamination of these planned activities. The basin is a good example of the fact that the final risk map does not include all the information that might be required by an end user. However, to ascertain the risk which might be posed by future developments, the planner would also require access to the intrinsic vulnerability map and appropriate specific vulnerability maps that are available.

\section{Acknowledgements}

Thanks are due to the anonymous reviewer of Journal of Water Resource and Protection for reviewing and improving the manuscript.

Thanks and gratitude are due to the Deanship of Scientific Research at the University of Jordan for supporting and sponsoring this research. This research has accomplished during the sabbatical leave sponsored from the University of Jordan starting from the spring semester 2013-2014.

\section{References}

[1] Sudhir, S., Srivastava, A., Pandey, A. and Gautam, S. (2013) Integrated Assessment of Groundwater Influenced by a Confluence River System: Concurrence with Remote Sensing and Geochemical Modelling. Water Resources Management, 27, 4291-4313. http://dx.doi.org/10.1007/s11269-013-0408-y

[2] Wang, J., He, J. and Chen, H. (2012) Assessment of Groundwater Contamination Risk Using Hazard Quantification, a Modified DRASTIC Model and Groundwater Value, Beijing Plain, China. Science of the Total Environment, 432, 216-226. http://dx.doi.org/10.1016/j.scitotenv.2012.06.005

[3] Zwahlen, F. (2003) Vulnerability and Risk Mapping for the Protection of Carbonate (Karst) Aquifers. Final Report (COST Action 620). European Commission, Directorate-General XII Science, Research and Development, Brussels, 297.

[4] Aller, L., Bennet, T., Lehr, J.H. and Petty, R.J. (1985) DRASTIC: Standardized System for Evaluating Ground Water Pollution Potential Using Hydrogeologic Settings. US EPA, Oklahoma.

[5] Vrba, J. and Zoporozec, A. (1994) Guidebook on Mapping Groundwater Vulnerability. Vol. 16, IAH-International Contributions to Hydrogeology, Hannover, 131.

[6] Babiker, I.S., Mohamed, A., Hiyama, T. and Kato, K. (2005) A GIS-Based DRASTIC Model for Assessing Aquifer Vulnerability in Kakamigahara Heights, Gifu Prefecture, Central Japan. Science of the Total Environment, 345, 127-140. http://dx.doi.org/10.1016/j.scitotenv.2004.11.005

[7] Stigter, T.Y., Ribeiro, L. and Carvalho Dill, A.M.M. (2006) Evaluation of an Intrinsic and a Specific Vulnerability Assessment Method in Comparison with Groundwater Salinisation and Nitrate Contamination Levels in Two Agricultural Regions in the South of Portugal. Hydrogeology Journal, 14, 79-99. http://dx.doi.org/10.1007/s10040-004-0396-3

[8] Hoelting, B., Haertlé, T., Hohberger, K., Nachtigall, K., Villinger, E., Weinzierl, W. and Wrobel, J. (1995) Konzept zur Ermittlung der Schutzfunktion der Grundwasserüberdeckung. Geologisches Jahrbuch Reihe C, 63, 5-24, Hannover.

[9] Gogu, R. and Dassargues, A. (2000) Current Trends and Future Challenges in Groundwater Vulnerability Assessment Using Overlay and Index Methods. Environmental Geology, 39, 549-559. http://dx.doi.org/10.1007/s002540050466

[10] Goldscheider, N. (2005) Karst Groundwater Vulnerability Mapping: Application of a New Method in the Swabian Alb, Germany. Hydrogeology Journal, 13, 555-564. http://dx.doi.org/10.1007/s10040-003-0291-3

[11] Mimi, Z. and Assi, A. (2009) Intrinsic Vulnerability, Hazard and Risk Mapping for Karst Aquifers: A Case Study. Journal of Hydrology, 364, 298-310. http://dx.doi.org/10.1016/j.jhydrol.2008.11.008

[12] Mahamid, I. and Thawaba, S. (2010) Multi Criteria and Landfill Site Selection Using GIS: A Case Study from Palestine. The Open Environmental Engineering Journal, 3, 33-41. http://dx.doi.org/10.2174/1874829501003010033

[13] Al Kuisi, M., Al-Qinna, M., Margane, A. and Aljazzar, T. (2009) Spatial Assessment of Salinity and Nitrate Pollution in Amman Zarqa Basin: A Case Study. Environmental Earth Science, 59, 117-129. http://dx.doi.org/10.1007/s12665-009-0010-z

[14] Al Kuisi, M. and Abdel-Fattah, A. (2010) Groundwater Vulnerability to Selenium in Semi-Arid Environments: Amman 
Zarqa Basin, Jordan. Environmental Geochemistry and Health, 32, 107-128. http://dx.doi.org/10.1007/s10653-009-9269-y

[15] (DOS) Department of Statistics. (2010) Estimation of Population by Governorate. Department of Statistics, Amman.

[16] Quennel, A. (1951) The Geology and Mineral Resources of Trans-Jordan. Colonial Geology and Mineral Resources, 2, 85-115.

[17] Abed, A., Sadaqa, R. and Al Kuisi, M. (2008) Uranium and Potentially Toxic Metals during the Mining, Beneficiation, and Processing of Phosphorite and Their Effects on Ground Water in Jordan. Mine Water and the Environment, 27, 171-182. http://dx.doi.org/10.1007/s10230-008-0039-3

[18] (NRA)Natural Resources Authority Geology Directorate. (2004) Geology Map of Amman Zarqa Basin. Scale 1:50,000. Natural Resources Authority Geology Directorate, Amman.

[19] Abed, A. (2000) Geology of Jordan, Water and Environment (in Arabic). Jordan Geological Association, Jordan.

[20] Mikbel, S. and Zacher, W. (1986) Fold Structures in Northern Jordan. Neues Jahrbuch für Geologie und Paläontologie, 4, 248-256, Stuttgart.

[21] (NWMP) National Water Master Plan. (2004) Groundwater Resources. Vol. VI, Ministry of Water and Irrigation, Amman, 350.

[22] Margane, A. (2003) Guideline for Groundwater Vulnerability Mapping and Risk Assessment for the Susceptibility of Groundwater Resources to Contamination. BGR and ACSAD, Damascus, 177.

[23] Hunting Technical Services, Soil Survey and Land Research Centre. (1993) The Soils of Jordan. Ministry of Agriculture, National Soil Map and Land Use Project, Level 1: Reconnaissance Soil Survey (Scale 1:250,000), 3 Volumes, Amman.

[24] Hunting Technical Services, Soil Survey and Land Research Centre. (1994) The Soils of Jordan. Ministry of Agriculture, National Soil Map and Land Use Project, Level 2: Semi Detailed Studies (Scale 1:50,000), 3 Volumes, Amman.

[25] Margane, A., Hobler, M., Almomani, M. and Subah, A. (2002) Contributions to the Groundwater Resources of Northern and Central Jordan Jordan. Geologisches Jahrbuch Reihe C, 68, 52, Hannover.

[26] Al-Qinna, M., Salahat, M. and Shatnawi, Z. (2008) Effect of Carbonates and Gravel Contents on Hydraulic Properties in Gravely-Calcareous Soils. Dirasat, Agricultural Sciences, 35, 145-158.

[27] Breshears, D., Myers, B. and Barnes, J. (2009) Horizontal Heterogeneity in the Frequency of Plant-Available Water with Woodland Intercanopy-Canopy Vegetation Patch Type Rivals that Occuring Vertically by Soil Depth. Ecohydrology, 2, 503-519. http://dx.doi.org/10.1002/eco.75

[28] Bodenkunde, A.G. (1996) Bodenkundliche Kartieranleitung. 4th Edition, Schweizerbart’sche Verlagsbuchhandlung, Stuttgart, Hannover.

[29] van Genuchten, M. (1980) A Closed-Form Equation for Predicting the Hydraulic Conductivity of Unsaturated Soils. Soil Science Society of America Journal, 44, 892-898. http://dx.doi.org/10.2136/sssaj1980.03615995004400050002x

[30] Gee, G.W. and Bauder, R.H. (1986) Particle-Size Analysis. In: Klute, A., Ed., Methods of Soil Analysis, 2nd Edition, Part 1, ASA, Madison, 383-411.

[31] Margane, A. and Hobler, M. (1994) Groundwater Resources of Northern Jordan, Vol. 3: Structural Features of the Main Hydrogeological Units in Northern Jordan. BGR \& WAJ, BGR Archive No. 118702:1-3, 57, Amman. 